\title{
Influenza, Respiratory Syncytial Virus, and Pneumonia in Glasgow, 1962-5
}

\author{
N. R. GRIST,* M.B., CH.B., B.SC., F.R.C.P.ED., M.C.PATH.; CONSTANCE A. C. ROSS,* M.D., M.C.PATH. \\ E. J. STOTT, $\dagger$ B.A.
}

Brit. med. F., 1967, 1, 456-457

In evaluating the importance of the different viruses associated with acute respiratory' illnesses particular attention is deserved by those viruses which contribute substantially to pneumonia, the most severe of these disease syndromes. Early studies in Glasgow (Grist and Landsman, 1955 ; Grist, 1959) showed good correspondence between peaks of pneumonia notifications and outbreaks of influenza, usually in the first quarter of the year, as had also been reported by Stuart-Harris (1953). In infants, however, notifications of pneumonia showed independent peaks, usually in the last quarter of the year, suggesting that some other agent was important in this age group (Russell, 1957).

It became possible to explore this further with the help of recent technical advances-notably the development of diagnostic techniques for respiratory syncytial virus, which is now known to be the major cause of epidemic bronchiolitis of young children (Beem et al., 1960; Chanock et al., 1961 ; McClelland et al., 1961). The present paper relates pneumonia notifications from the City of Glasgow to infections by influenza and respiratory syncytial viruses diagnosed at this laboratory during 1962-5.

\section{Materials and Methods}

Corrected monthly notifications of acute primary pneumonia and influenzal pneumonia were obtained from the Health and Welfare Department of the City of Glasgow.

Specimens of respiratory secretion and/or paired sera were obtained from children and adults in hospital and general practice with acute respiratory illnesses; they were examined by standard virological techniques described elsewhere (Ross et al., 1964 ; Grist et al., 1966). Influenza or respiratory syncytial virus infections were diagnosed on the basis of virus isolation and/or a fourfold or greater rise in complement-fixing antibody titre. The majority of these infections and nearly all the respiratory syncytial virus infections were from the Glasgow area.

\section{Results}

The monthly notifications of pneumonia in different age groups showed peak incidences in the first quarter of each year in those over the age of 15 years. Those under the age of 5 years showed peak incidences in the last quarter of each year. The figures for pneumonia in those aged 5 to 15 were small and showed an indistinct intermediate pattern. For simplicity the data were considered in two contrasting groups-namely, "adults" (over 15 years old) and "children" (under 5 years old).

Fig. 1 relates monthly notifications of pneumonia in adults to cases of influenza diagnosed in the Ruchill laboratory (mainly type B in 1962 and type A in 1963 and 1965). It shows good

\footnotetext{
* University Department of Infectious Diseases and Regional Virus Laboratory, Ruchill Hospital, Glasgow.

t Present address: Common Cold Research Unit, Harvard Hospital. Salisbury, Wilts.
}

correlation between the peaks of pneumonia prevalence and the outbreaks of influenza, though throughout the period no considerable outbreak of influenza occurred and we detected no case in 1964.

Fig. 2 relates pneumonia notifications in children over the same period to respiratory syncytial virus infections detected by tests applied to an increasing population from July 1962 onwards. It shows good correlation between peaks of pneumonia prevalence and the outbreaks of respiratory syncytial virus infection diagnosed in the laboratory. Though pneumonia notifications were fewer in the last two winters, expansion of the scale of laboratory testing provided larger numbers of respiratory syncytial virus diagnoses.

Fig. 3 relates the pneumonia notifications in the two groups to one another and to the outbreaks of influenza and respiratory syncytial virus infection. The dissociation of the curves described by Russell (1957) is well shown: thus in the early

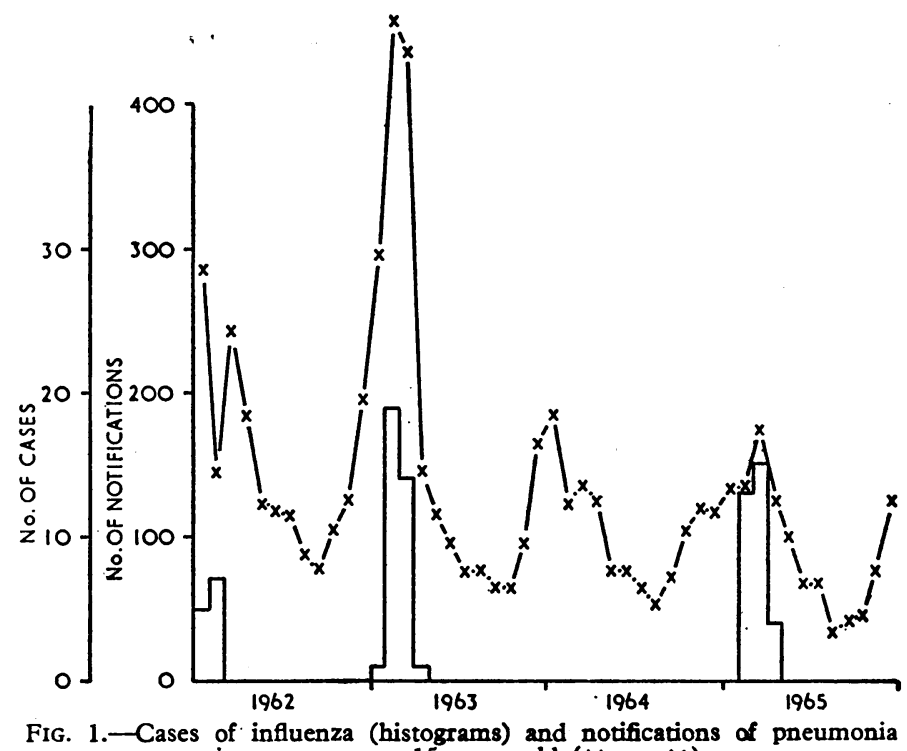

FIG. 1.-Cases of influenza (histograms) and notifications of pneumonia in persons over 15 years old $(x-x)$.

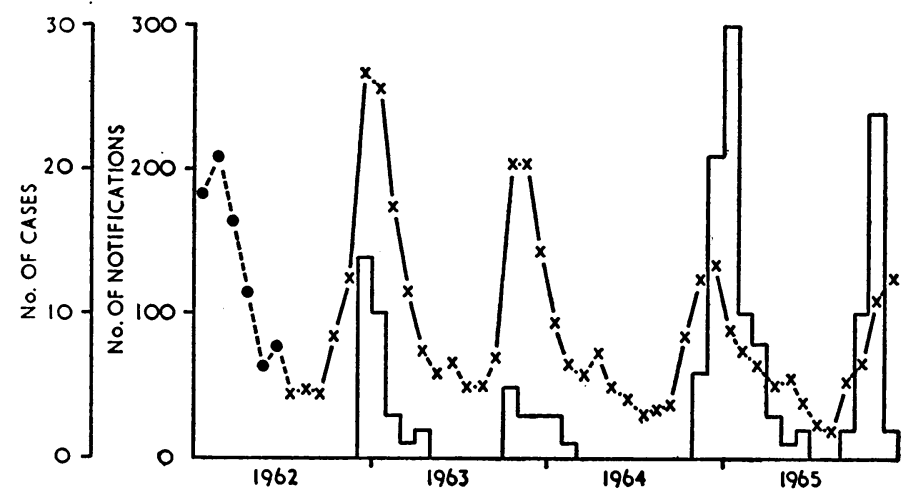

FIG. 2.-Cases of respiratory syncytial virus infection (histograms) and FIG. 2.- Cases of respiratory syncytial virus infection (histograms) and notifications of pneumonia in children under 5 years old before $(x)$ introduction of respiratory syncytial virus testing. 
months of 1963 the notifications for children were falling after the peak of the respiratory syncytial outbreak, while those for adults were rising as the influenza outbreak developed.

\section{Discussion}

Our findings support the view that influenza and respiratory syncytial viruses are outstandingly important as causes of epidemic respiratory disease of pneumonic severity in adults and

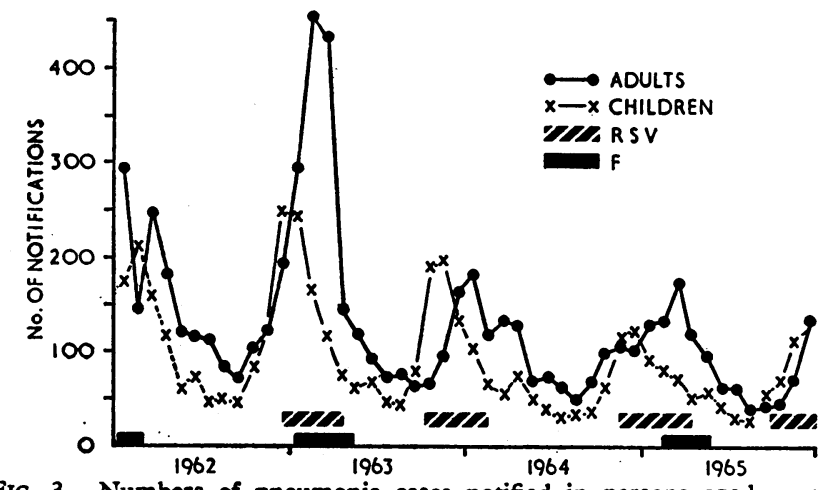

FIG. 3.-Numbers of pneumonia cases notified in persons aged over 15 and under 5 years in relation to outbreaks of influenza (F) and respiratory syncytial virus (R.S.V.) infection.

young children respectively. No other viruses have been found to cause regular elevations of such magnitude in the pneumonia statistics of the community.

In comparing the observations in adults and in young children it may be noted that postinfective immunity is usually sufficient to prevent reinfections with respiratory syncytial virus of more than trivial severity in adult life. Antigenic variation by influenza virus makes possible reinfections throughout life with periodic epidemics affecting the adult population, but it is less obvious why influenza infections in early childhood

\title{
Studies on an Epidemic of Respiratory Disease caused by Mycoplasma pneumoniae
}

\author{
T. FEIZI,* M.B., B.S., M.R.C.P. ; H. MACLEAN, $†$ M.B., CH.B., B.SC. ; R. G. SOMMERVILLE, $\ddagger$ M.D., M.C.PATH. \\ J. G. SELWYN,§ M.D., M.C.PATH.
}

Brit. med. F., 1967, 1, 457-460

Mycoplasma pneumoniae is recognized as a common cause of acute lower respiratory disease in military and civilian populations in the U.S.A. (Chanock et al., 1963 ; Forsyth et al., 1965 ; Grayston et al., 1965). Though less information is available on the prevalence of infection by that organism in this country, reports by Goodburn et al. (1963), Marmion and Hers (1963), Andrews (1965), and Watson (1965), suggest that M. pneumoniae infection is by no means rare.

We report an outbreak of acute respiratory disease in a country practice in Dumfriesshire, Scotland, which lasted from January to June 1965 , and in which $M$. pneumoniae appeared to be the commonest aetiological agent.

\footnotetext{
- Assistant Lecturer, Department of Medicinę, Royal Free Hospital, London W.C.1.

should cause so little serious illness. This paradox will be considered elsewhere.

Pneumonia and acute bronchiolitis of infants due to respiratory syncytial virus is often serious and sometimes life-threatening. The severity and periodic epidemic prevalence of this infection and its major contribution to serious respiratory disease in early life justify efforts to devise effective control measures by prophylactic vaccines or antiviral chemotherapy.

\section{Summary}

Comparison of pneumonia notifications with laboratorydiagnosed influenza and respiratory syncytial virus infections in Glasgow during 1962-5 confirmed the importance as causes of pneumonia of influenza in adults and respiratory syncytial virus in young children. Specific control measures are required for respiratory syncytial virus infections in early life.

We are grateful to Dr. W. A. Horne, Medical Officer of Health for Glasgow, for access to pneumonia statistics kindly provided by Miss Mary Knox. We also thank our clinical colleagues in hospital and general practice for their co-operation in these studies, and our technical staff for their assistance.

\section{REFERENCES}

Beem, M., Wright, F. H., Hamre, D., Egerer, R., and Oehme, M. (1960). New Engl. ₹. Med., 263, 523 .

Chanock, R. M., Kim, H. W., Vargosko, A. J., Deleva, A., Johnson, K. M., Cumming, C., and Parrott, R. H. (1961). F. Amer. med. Ass., 176, 647.

Grist, N. R. (1959). Scot. med. 7., 4, 446.

- and Landsman, J. B. (1955). Glasg. med. 7., 36, 69

Ross, C. A. C., Bell, E. J., and Stott, E. J. (1966). Diagnostic Methods in Clinical Virology. Oxford.

McClelland, L., Hilleman, M. R., Hamparian, V. V., Ketler, A., Reilly, C. M., Cornfeld, D., and Stokes, J. (1961). New Engl. F. Med., 264, 1169

Ross, C. A. C., Stott, E. J., McMichael, S., and Crowther, I. A. (1964) Arch. ges. Virusforsch., 14, 553.

Russell, S. J. M. (1957). Scot. med. 7., 2, 88.

Stuart-Harris, C. H. (1953). Influenza and Other Virus Infections of the Respiratory Tract. London.
Of the 113 patients studied 93 were from the country practice of one of us (H.M.); the remaining 20 were patients with acute respiratory infections admitted during this period to the Royal Infirmary in Dumfries and to the near-by Lochmaben Chest Hospital. We included not only patients seeking medical attention on account of acute respiratory symptoms, but, whenever possible, other members of their families or their close contacts. Almost all the contacts questioned had had recent respiratory symptoms. In all, 21 families, in addition to 48 individual patients, were studied. Their ages ranged from 1 to 78 years.

Whenever possible blood was taken at the onset of illness and again 10 to 20 days later. Some patients sought medical attention after the first week of illness, and many of the contacts were first seen during or after the convalescent phase. Paired 